\title{
Budaya dan Identitas Nasional dalam Alih Manajemen Sumber Daya Manusia pada Perusahaan Multinasional
}

\author{
Dasmadi \\ Fakultas Ekonomi Universitas Boyolali \\ Email: dasmadiboyolali82@gmail.com
}

\section{Article Info \\ Article History \\ Received: 2021-11-20 \\ Revised: 2021-12-15 \\ Published: 2022-01-07}

Keywords:

National Culture

Management Transfer;

Multinational;

Companies.

\begin{abstract}
Every country must have a national culture that provides cultural guidance on how the character tendencies of its citizens are formed. On the other hand, the global business world allows global corporations or often called multinational companies (MNCs) to invest in countries to invest by establishing subsidiaries or branches in various countries. This paper will examine the role of a country's national culture in shifting the management of Human Resources (HR) from the center of a Multinational Company (MNC) to its branches or subsidiaries in various countries. This article is a literature study with a qualitative approach with a descriptive method, namely by collecting, analyzing, and making a description of all conditions - situations from the data that has been collected. The data are taken from various sources such as books, journals, and others. Data analysis was carried out by data reduction, which was then analyzed based on the theories chosen in this study and presented in the form of scientific narratives. The results show that the organizational culture prevailing in subsidiaries may differ from country to country in which they operate. Furthermore, it can be concluded that labor management practices can be transferred to multinational companies (MNCs) which will depend on the national culture of the country. This change in the pattern of HR management is generally mediated by the organizational culture (which is influenced by local/local culture) prevailing in the subsidiaries.
\end{abstract}

\begin{tabular}{l}
\hline Artikel Info \\
\hline Sejarah Artikel \\
Diterima: 2021-11-20 \\
Direvisi: 2021-12-15 \\
Dipublikasi: 2022-01-07
\end{tabular}

Kata kunci: Budaya Nasional; Alih Manajemen; Perusahaan; Multinasional. \begin{abstract}
Abstrak
Setiap negara pasti memiliki budaya nasional yang memberikan panduan kultural bagaimana kecenderungan karakter warga negaranya terbentuk. Disisi lain, dunia bisnis global memungkinkan korporasi dunia atau sering disebut perusahaan multinasional (MNC) melakukan investasi pada negara - negara menanam investasi dengan mendirikan anak perusahaan atau cabangnya di berbagai negara. Tulisan ini akan mengkaji tentang peran budaya nasional suatu negara dalam mengalihka pengelolaan Sumber Daya Manusia (SDM) dari sentral Perusahaan Multinasional (MNC) ke cabang - cabang atau anak perusahaannya di berbagai negara. Artikel ini merupakan studi pustaka pendekatan kualitatif dengan metode deskriptif yaitu dengan cara mengumpulkan, menganalisis, dan membuat gambaran segala kondisi - situasi dari data yang telah terkumpul. Data - data diambil dari berbagai sumber seperti buku, jurnal,dan lainnya. Analisis data dilakukan dengan reduksi data, yang selanjutnya dianalisis berdasarkan teori teori yang dipilih dalam penelitian ini dan disajikan dalam bentuk narasi ilmiah. Hasil penelitian menunjukkan bahwa budaya organisasi yang berlaku di anak perusahaan bisa berbeda dari satu negara ke negara di mana mereka beroperasi. Selanjutnya dapat disimpulkan bahwa praktik pengelolaan ketenagakerjaan dapat dialihkan pada perusahaan multinasional (MNC) akan sangat tergantung pada budaya nasional negara tersebut. Alih pola pengelolaan SDM ini umumnya dimediasi oleh budaya organisasi (yang dipengaruhi budaya lokal/setempat) yang berlaku di anak perusahaan.
\end{abstract}

\section{PENDAHULUAN}

Perusahaan multinasional atau sering disebut dengan MNCs (Multi National Corporations) adalah perusahaan yang berkantor pusat di suatu negara tertentu dan kegiatannya di lebih dari satu negara di dunia. SDM internasional selama dua dekade terakhir, bergerak aktif untuk memperluas wilayahnya (Sharma \& Matta, 2018). Makalah ini karena itu berfokus pada gambaran perusahaan multinasional, praktek manajemen sumber daya manusia internasional yang digunakan di perusahaan multinasional dan selanjutnya bagaimana mekanisme organisasi diadopsi untuk alih daya menuju ke negara-negara berkembang, terutama melalui anak perusahaan yang dimiliki. Ada banyak faktor eksternal seperti strategi dan struktur perusahaan multinasional (Deresky, 2017) dll. yang mempeng- 
aruhi operasi korporasi internasional itu. Diantara faktor-faktor tersebut, budaya nasional menjadi fokus utama dan oleh karena itu artikel ini mengkaji pengaruhnya terhadap transfer manajemen SDM internasional ke perusahaan multinasional.

Oleh karena itu penulis berpendapat bahwa budaya nasional negara tuan rumah memiliki pengaruh penting pada budaya organisasi anak perusahaannya. Pengelolaan SDM adalah interaksi (aktivitas personel, negara aktivitas dan jenis karyawan), yakni meliputi (1). Aktivitas manajemen personalia yang luas mulai dari perolehan, alokasi, dan penggunaan. (2) Kategori negara tuan rumah di mana anak perusahaan berada , (3) Negara asal tempat perusahaan tersebut berada, (4) Negara-negara tertentu yang menjadi sumber pekerjaan, keuangan, dan input lainya, dan (5) Jenis pekerja yakni warga negara dari negara tuan rumah, warga negara dari negara asal dan warga negara dari negara ketiga.

Menurut Tayeb (2005), dengan ekspansi aktivitas dan persaingan bisnis global baru-baru ini, perusahaan multinasional perlu lebih memperhatikan praktik manajemen mereka pada sumber daya manusia, yang berada di luar pengelolaan ekspatriat. Oleh karena itu, Scullion (1995) mengidentifikasi manajemen SDM sebagai area penting berdasar kajiannya berikut: (1) Kekurangan manajer internasional menjadi masalah yang berkembang bagi perusahaan internasional, (2) Keberhasilan implementasi strategi global di semua aktivitas global akan tergantung pada keberadaan ketersediaan manajer internasional yang berpengalaman, (3) Kegagalan bisnis di lingkungan internasional sering dikaitkan dengan manajemen sumber daya manusia yang buruk, (4) Kegagalan kaum ekspatriat tetap menjadi masalah utama bagi banyak perusahaan internasional.

Ghoshal dan Bartlett (1990) mendefinisikan perusahaan multinasional sebagai sekelompok organisasi yang tersebar secara geografis yang mencakup kantor pusat dan beberapa anak perusahaan nasional, sedangkan Dunning (1993) mendefinisikan perusahaan multinasional sebagai perusahaan yang melakukan investasi langsung di perusahaan negara asing. dan memiliki dan mengontrol aktivitas nilai tambah di lebih dari satu Negara, ketika perusahaan-perusahaan ini beroperasi di benua yang berbeda, salah satu masalah besar yang mereka hadapi adalah bagaimana menjalankan bisnis seefisien mungkin. Dengan pentingnya sumber daya manusia dalam menentukan keberhasilan perusahaan multinasional, kemudian banyak penelitian yang dilakukan yang mencakup ruang lingkupnya secara mendalam. Berbeda dengan dua dekade lalu, dimana perusahaan multinasional lebih berfokus pada masuknya strategi perusahaan multinasional di pasar luar negeri dan pendekatan komersial yang diadopsi oleh mereka daripada pada praktik manajemen.

Dengan ekspansi besar-besaran kegiatan bisnis perusahaan multinasional di pasar luar negeri, fokus penelitian juga pada pengelolaan sumber daya manusia ekspatriat, repatriasi karyawan, transfer dan diseminasi praktik manajemen sumber daya manusia, peningkatan produktivitas, interkultural. manajemen, pengembangan kepemimpinan global dan manajemen keragaman. dll. Pengelolaan SDM Internasional adalah manajemen sumber daya yang efektif di pasar global untuk mencapai keunggulan kompetitif bagi perusahaan multinasional dan membuat mereka sukses di seluruh dunia. Dengan demikian pengertian manajemen SDM internasional diselaraskan dengan kegiatan yang terkait dengan pengelolaan sistem manajemen multinasional dengan beragam aktivitas, fungsi dan proses yang bertujuan untuk menarik, mengembangkan dan memelihara sumber daya manusia perusahaan multinasional untuk operasi lokal dan luar negeri. Dalam skenario ini, Sumber Daya Manusia (SDM) memainkan peran penting dalam proses internasionalisasi dengan berkontribusi pada perusahaan multinasional yang efektif dan efisien. (Buckley dan Casson, 2016).

\section{METODE PENELITIAN}

Kajian ini menggunakan pendekatan kualitatif dengan metode deskriptif yaitu dengan cara mengumpulkan, menganalisis, membuat gambaran dan mempersingkat segala kondisi dan situasi dari data yang telah terkumpul. Penelitian ini merupakan penelitian kualitatif reflektif dengan pendekatan studi Pustaka. Data - data diambil dari berbagai sumber seperti buku, jurnal,dan lainnya. Analisis data yang dilakukan untuk menjawab permasalahan yang ada pada penelitian ini adalah reduksi data, yang selanjutnya dianalisis berdasarkan teori teori yang dipilih dalam penelitian ini dan disajikan dalam bentuk narasi ilmiah.

\section{HASIL DAN PEMBAHASAN \\ Difusi Manajemen SDM Internasional Di Korporasi Global}

Dengan ekspansi perusahaan multinasional yang lebih besar di seluruh dunia dan dengan 
identifikasi praktik manajemen sumber daya manusia sebagai penentu utama keberhasilan atau kegagalan dalam bisnis internasional, maka fokus kajian ini adalah penyebaran praktik manajemen sumber daya manusia (Chiang, Lemański \& Birtch , 2017). Praktik diseminasi SDM Internasional mendapat perhatian yang meningkat, terutama karena diharapkan memiliki pengaruh yang signifikan terhadap kinerja dan daya saing perusahaan multinasional dan anak perusahaannya (Chiang et al., 2017) Pengalihan kebijakan dan praktik ini, termasuk praktik SDM, merupakan proses yang sangat kompleks terkait dengan kebutuhan transfer antara dua lokasi geografis dengan karakteristik budaya yang berbeda. Harus diperhitungkan bahwa praktik tersebut berasal dari lingkungan kelembagaan yang sangat spesifik dan oleh karena itu ditempatkan di domain yang sama sekali berbeda, yang harus dilakukan dengan lebih hati-hati (Kornelakis dan Voskeritsian, 2015)

Beberapa perusahaan multinasional beradaptasi dengan praktik budaya lokal dan nasional selama operasi mereka di luar negeri, karena globalisasi telah mendukung standarisasi elemen tertentu dari sistem manajemen, khususnya berkaitan dengan personel, budaya, dan perilaku. Identifikasi perusahaan multi- nasional, dalam tipologi Bartlett dan Ghoshal (1990), dapat diklasifikasikan menjadi empat kategori menurut tingkat integrasi global dan daya tanggap lokal, yaitu - organisasi internasional, organisasi transnasional, organisasi global dan organisasi multinasional. Selanjutnya organisasi multinasional bertindak sebagai sarana untuk menentukan strategi bisnis perusahaan dalam internasionalisasi kultur mereka (Cavusgil, Knight dan Reisenberger, 2012).

Oppong (2018) berpendapat bahwa perusahaan mungkin menemukan pedoman yang memadai dalam semua kegiatan internasional mereka, namun praktik manajemen sumber daya manusia lebih rentan terhadap pengaruh budaya lokal daripada kebijakan dan strategi umum perusahaan tersebut. Selain itu, perusahaan yang mengimpor SDM dari luar negeri harus disesuaikan agar dapat diterapkan dengan mempertimbangkan konteks budaya dan non-budaya lokal mereka (Prancis, 2015). Ini menunjukkan peran penting yang dimainkan budaya nasional dalam menerjemahkan kebijakan dan praktik personel ke anak perusahaan, meskipun mungkin ada kesamaan yang signifikan antara negara-negara di wilayah geografis yang sama.
Budaya nasional diidentifikasi mempengaruhi penyebaran praktik pengelolaan SDM, budaya nasional adalah faktor yang paling berpengaruh dalam SDM internasional (Singh, Pattnaik, Lee dan Gaur, 2019). Pertanyaan yang dibahas di sini adalah apakah dapat diterima untuk mengklaim bahwa budaya nasional memainkan peran dominan dalam konteks bisnis global saat ini, di mana sebagian besar perusahaan cenderung berubah menjadi organisasi global dengan praktik bisnis yang homogen. Globalisasi adalah proses yang mencakup strategi integrasi global yang bertujuan untuk mengembangkan produk yang relatif terstandarisasi dengan daya tarik global, serta rasionalisasi operasi global (Pieterse, 2019). Dengan latar belakang ini, perusahaan multinasional dapat dan akan mendesiminasi pengelolaan SDM dari negara asal mereka langsung ke anak perusahaan mereka yang beroperasi di negara tuan rumah, yang sebagian besar adalah negara berkembang.

Budaya menghargai perilaku mendorong kecenderungan untuk mengembangkan dan mengadopsi inovasi baru, sementara budaya yang memperkuat kepatuhan, pemangku kepentingan, dan kontrol atas masa depan tidak mungkin menampilkan perilaku inovatif dan berani mengambil risiko. Praktik manajemen kinerja yang digunakan oleh perusahaan induk mungkin harus selaras dengan nilai-nilai budaya ini. Bahkan jika perusahaan induk berada di negara yang mempromosikan individualisme sementara anak perusahaan berada dalam budaya kolektivis, praktik penghargaan individualistis mungkin tidak diterima dengan baik.

De Cieri dan Dowling (1999) dalam Strategic Integrating Framework of Human Resource Management in Multinational Corporations mengidentifikasi budaya nasional termasuk dalam kategori luas faktor eksogen. Pada setiap ketika perusahaan multinasional mencoba untuk mantransfer praktik pengelolaan personel mereka ke anak perusahaan di luar wilayah, dimana budaya nasional dapat memainkan peran dominan dalam alih kelola SDM itu.

Menurut Wilk (2018), teori ekonomi juga mengakui pentingnya budaya untuk membentuk perilaku individu dan institusional. Selain itu, budaya nasional dapat dibagi menjadi empat kategori, yaitu individu, kelompok, organisasi, dan industri. Hal ini menunjukkan betapa pentingnya peran budaya bangsa dalam menciptakan budaya organisasi yang ada di tanah air. Budaya nasional mempengaruhi perilaku orang-orang di 
negara-bangsa dan, dengan demikian, perilaku ini ditunjukkan oleh orang-orang di tempat kerja, terlepas dari apakah itu perusahaan lokal atau anak perusahaan dari perusahaan multinasional asing lain (Brettel, Chomik \& Ratakan, 2015). Ini sesuai dengan fakta bahwa budaya organisasi anak perusahaan di berbagai negara di dunia perusahaan multinasional dapat berbeda.

\section{SIMPULAN DAN SARAN}

\section{A. Simpulan}

Kajian ini menganalisis peran budaya organisasi dalam mengalihkan tata kelola ketenagakerjaan ke anak perusahaan perusahaan multinasional. Ini berarti bahwa alih manajemen sumber daya manusia yang unik dari kantor pusat multinasional ke anak perusahaan mereka bergantung pada budaya organisasi anak perusahaan yang berlaku, di mana mereka aktif. Acapkali memang kesamaan antara anak perusahaan, tetapi kita juga melihat perbedaan. Ini menggambarkan kesulitan praktis untuk menciptakan budaya organisasi yang seragam di semua anak perusahaan. Pengelolaan SDM di perusahaan multinasional yang tak mudah memperlihatkan bahwa menciptakan organisasi global dengan integrasi global yang tinggi dan daya tanggap lokal yang rendah merupakan tantangan yang serius. Budaya organisasi anak perusahaan sedikit banyak dipengaruhi oleh budaya nasional budaya negara.

\section{B. Saran}

Terlepas dari sejauh mana perusahaan induk mencoba untuk mentransfer prosedur mereka ke anak perusahaan, perusahaaan multinasional harus membuat penyesuaian dan variasi tertentu untuk beradaptasi dengan budaya nasional. Singkatnya, disarankan agar praktik ketenagakerjaan di perusahaan multinasional dapat diubah sesuai dengan budaya nasional negara tersebut dan hubungan ini dimediasi oleh budaya organisasi yang berlaku di anak perusahaan.

\section{DAFTAR RUJUKAN}

Birkinshaw, J. (2016). Multinational corporate evolution and subsidiary development. Springer .

Buckley, P. J., \& Casson, M. (2016). The future of the multinational enterprise. Springer.
Cavusgil, S.T., Knight, G. \& Reisenberger, J.R. (2012). International Business: The New Realities. New Jersey: Prentice Hall.

Crane, D., Kawashima, N., \& Kawasaki, K. I. (2016). Culture and globalization theoretical models and emerging trends. In Global culture (pp. 11-36). Routledge.

De Cieri, H. and P.J. Dowling (1999) _Strategic human resource management in multinational enterprises: theoretical and empirical developments', in P.M. Wright, L.D. Dyer, J.W. Boudreau, and G.T. Milkovich (eds) Research in Personnel and Human Resources Management: Strategic Human Resources Management in the Twenty-First Century, Supplement 4. CT: Stamford, JAI Press.

Driskill, G. W. (2018). Organizational culture in action: A cultural analysis workbook. Routledge.

Dunning JH. 1993.Multinational Enterprises and the Global Economy. Addison-Wesley: New York.

Imansyah, M. N., \& Asmedy, A. (2021). Akselerasi covid-19 pada proses pembelajaran di era pendidikan 4.0.JPPI (Jurnal Penelitian Pendidikan Indonesia), 7(2), 279-284.

Laurent, A. (1986) _The cross-cultural puzzle of international human resource management',25(1).

Lunnan, R., Lervik, J.L.K., Traavik, L E.M., Nilsen, S. M., Amdam, R.P. \&. Hennestad. B.W. (2005). Global Transfer of Management Practices across nations and MNC subcultures. The Academy of Management Executive. 19 (02). pp77-80.

Morgan, G. (1986). International Human Resource Management: fact or fiction. Personnel Administrator, 31 (9): pp43-47.

Myers, M.D. \& Tan, F.B. (2002). Beyond Models of National Culture in Information Systems Research Journal of Global Information Management,.10(02).

Myloni, B., Harzing, A. \& Mirza, H. (2003) Human resource management in Greece Have the colors of culture faded away? International Journal of CrossCultural Management, 4 (1), pp. 59-76. 
Nakhle, S.F. (2011, May). The transfer of human resource practices from American and European multinational companies to their Lebanese subsidiaries: A study of the hostcountry effects and of the standardizationadaptation dilemma. (Doctoral thesis). University of Fribourg, Switzerland.
Oppong, N. Y. (2018). Human resource management transfer challenges within multinational firms: From tension to best fit. Management Research Review, 41(7), 860877. 